\title{
Analysis of lineament swarms in a Precambrian metamorphic rocks in India
}

\author{
Tapas Acharya ${ }^{1,3, *}$ and Sukumar Basu MalliK ${ }^{2}$ \\ ${ }^{1}$ Department of Geology, Durgapur Government College, University of Burdwan, Durgapur 713 214, India. \\ ${ }^{2}$ Department of Geological Sciences, Jadavpur University, Kolkata 700 032, India. \\ ${ }^{3}$ Present Address: Department of Geology, Hooghly Mohsin College, University of Burdwan, \\ Chinsurah 712 101, India. \\ *Corresponding author.e-mail: tacharya3@yahoo.com
}

\begin{abstract}
Addressing the geologic significance of lineaments and their correlation with joints/fractures is still unclear. The present study attempts to analyse the lineament swarms developed in a Precambrian metamorphic terrain in India using both unfiltered and filtered techniques. The unfiltered analysis technique shows that the major lineament and fracture trends are oriented along EW and NS directions respectively, thus failing to provide any correlation between them. The application of domain-based filtering techniques identifies a highly predominant fracture-correlated lineaments in mica schist constituting the EW trending shear zone in the area. This correlation is not evident in the areas north and south of the shear zone, where the lineaments are consistently oriented along the foliation planes of the rocks and are designated as 'foliation correlated'. The present analysis indicates that the fracture frequency and the strain history may have played significant roles for the formation of fracture-correlated lineaments in the metamorphic terrain.
\end{abstract}

\section{Introduction}

Lineaments are natural, linear surface elements, interpreted directly from satellite imagery and geophysical map and have been called fracture traces, and many other names (Parizek 1976; Garza and Slade 1986; O'leary et al 1976) and also used for water resource investigations (Boyer and McQueen 1964; Brown 1994; Lattman and Parizek 1964; Peterson 1980; Mah et al 1995; Dhakate et al 2007) and structural geologic studies (Blanchet 1957; Henderson 1960; Hodgson 1961; Lattman and Segovia 1961; Caran et al 1982; Acharya et al 2007; Rahiman and Pettinga 2008; Kazemi et al 2009), considering lineaments as the surface expressions of joints/fractures or zone of joint concentration. Practical experiences of many hydrogeologists and petroleum geologists were that suggesting locations for dug wells, tube wells and drill wells in crystalline metamorphic and igneous terrain, based on lineament data, did not always yield a good success rate. Several studies show a significant deviation of lineaments from dominant joint/fractures (Lattman and Matzke 1961; Matzke 1961; Lipfert et al 2001; De'gnan and Clark 2002), demanding more investigations to analyse the lineaments in Precambrian metamorphic rocks.

The study area is located in and around Balarampur, Purulia district, West Bengal, India, within $23^{\circ} 02^{\prime} 47^{\prime \prime}-23^{\circ} 07^{\prime} 41^{\prime \prime} \mathrm{N}$ latitudes and $86^{\circ} 10^{\prime} 00^{\prime \prime}-86^{\circ} 19^{\prime} 02^{\prime \prime} \mathrm{E}$ longitudes (figure 1), which is underlain by jointed/fractured metamorphic rocks providing lineament swarms to carry out critical analysis of lineaments and their correlating

Keywords. Lineament; fracture; remote sensing; hydrology; data analysis. 


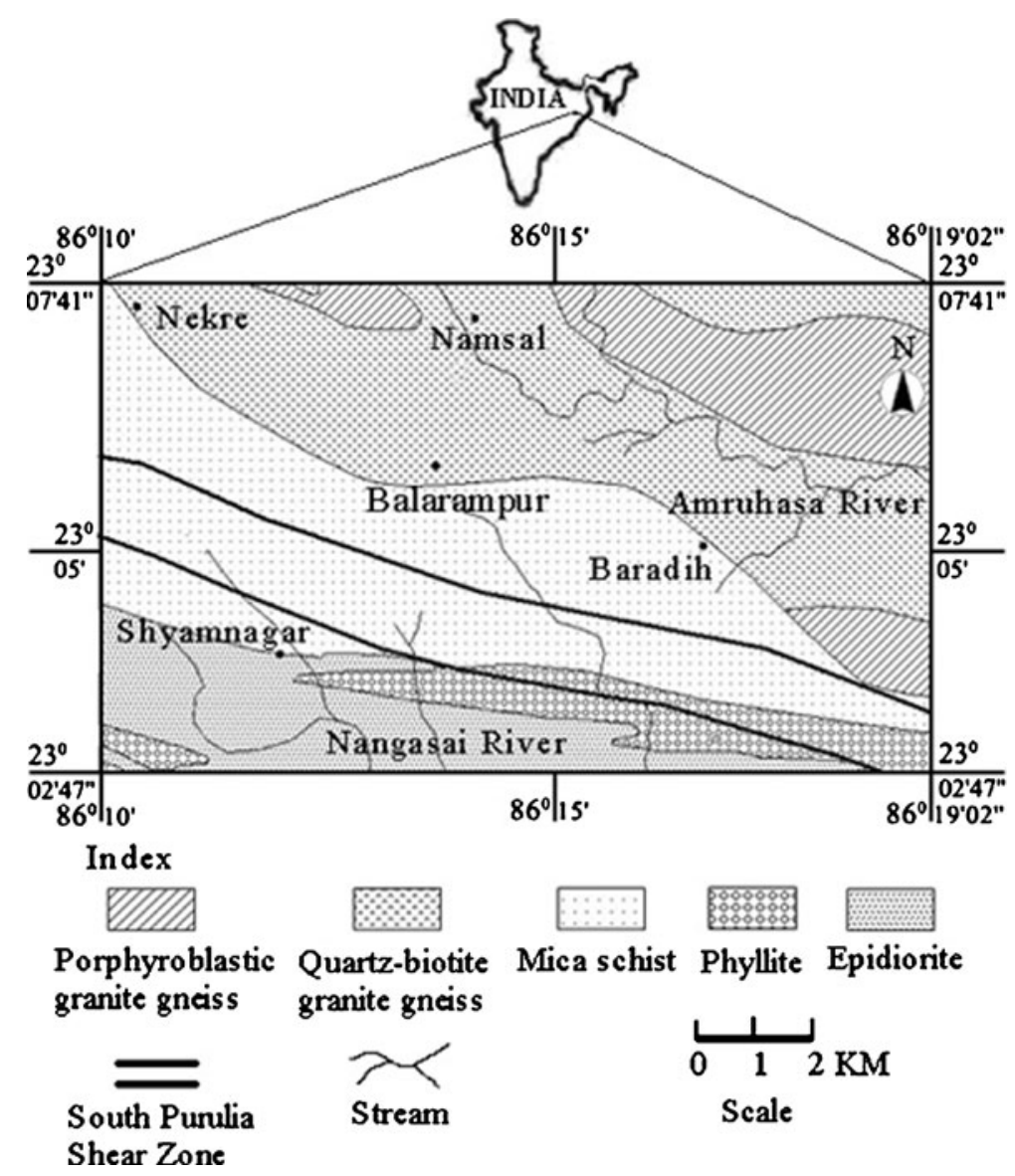

Figure 1. Geological map of the study area in Purulia district, West Bengal, India.

factors. Acharya and Chatterjee (2010) showed a good number of lineaments without any high yielding well-sites in the study area. There exists a few studies investigating lineaments (Acharya et al 2007) and subsurface bedrock fractures (Mallik et al 1983; Nag 1999) in and around Balarampur. Visual interpretation of lineaments in this area was made from IRS-P6 LISS III standard FCC imageries treating the lineaments literally as straight lines in the horizontal plane in 1:50,000 scale. Only 'geological lineaments' are extracted from the total lineaments in the study area $\left(\sim 132.9 \mathrm{~km}^{2}\right)$ by comparing with toposheetfeatures and excluding the "non-geological lineaments' after ground truth verification. 'Geological lineaments' and the structural data obtained by field studies have been compared, by taking into account the dominant azimuth sets, in the following three ways:

- unfiltered analysis,

- filtered, domain-based analysis, and

- filtered, discrete-analysis-based analysis techniques to identify fracture-correlated lineaments.

The ongoing electrical resistivity study supplements the results of this paper.

\section{Geological setup}

The study area is located at the junction of Chhotanagpur Granite Gneissic Complex (CGGC) and the Singhbhum Group of rocks (SG), exposing metamorphic rocks of Proterozoic age (Baidya 1992; Gupta and Basu 2000) (figure 1). At the north the CGGC is a part of the Chhotanagpur Craton consisting varieties of granite gneisses, such as quartz-biotite granite gneiss and porphyroblastic granite gneiss. The SG rocks, exposing at the south belongs to Singhbhum orogenic belt and comprises chiefly of mica schist and phyllite. NW-SE foliations are well developed both in the CGGC and in the metasedimentaries of Singhbhum Group (Geological quadrangle map 73-I 1948) due to tectonic stress along NS direction. The foliations in the area statistically dip high $\left(>57^{\circ}\right)$ towards north. The metasediments of SG are interlayered with basic bodies, locally described as epidiorite sills, which may have a strong genetic connection with the Dalma Volcanics (Geological quadrangle map 73-I 1948). Presence of more than one generation of minor folds indicates imprints of polyphase deformation of the rocks. Geometry of the first generation fold is not preserved due to absence 
of exposures of competent horizons. Evidences of shear forces acted along some EW trending nearly vertical weak planes during the third tectonic period (Geological quadrangle map, 73-I, 1948) are noticeable in the region of southern Purulia shear zone. CGGC was thrusted towards south over SG (Katti et al 2010). In this area such structural elements are mainly represented

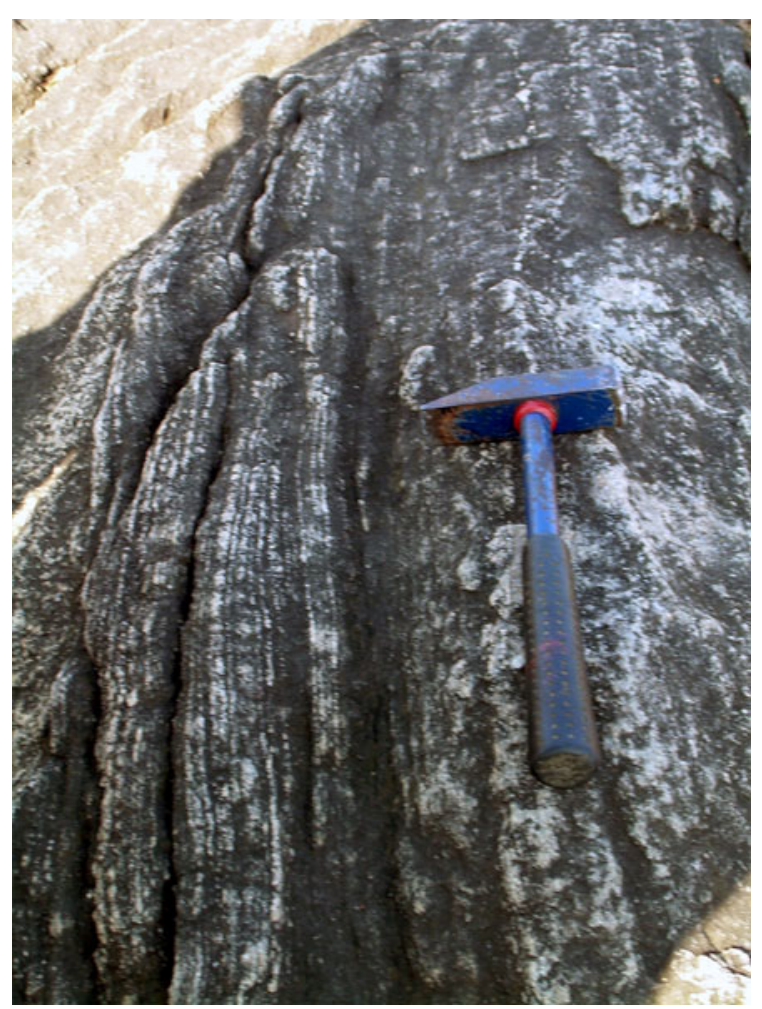

Figure 2. Grooves and furrows developed in the highly foliated granite gneiss due to differential weathering along foliation planes.

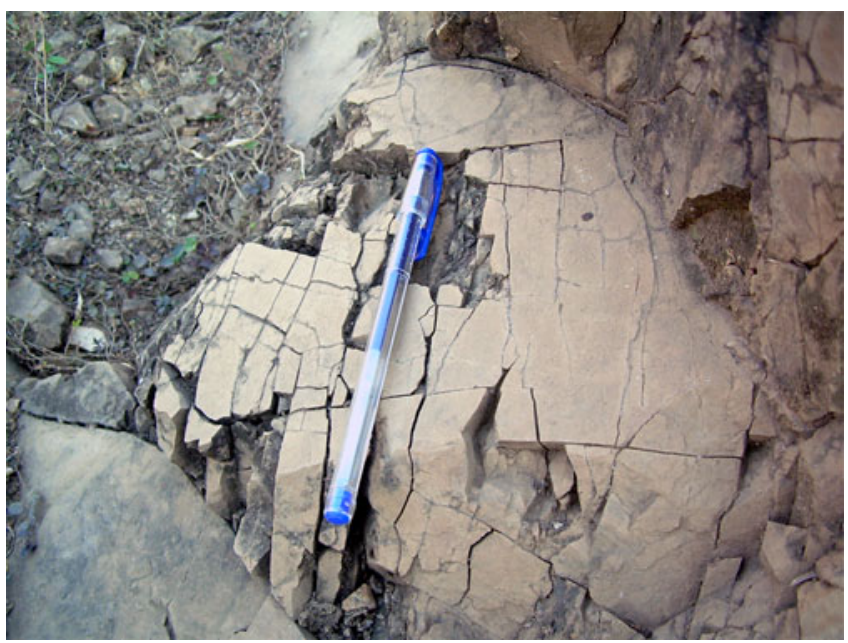

Figure 3. Well developed fractures in phyllite. by some shear-joints and fractures in the granitic rocks, pegmatites, quartz veins and metasediments. These shear joints, fractures and faults strike EW, in general, with $60^{\circ}$ to nearly vertical dips (Geological quadrangle map 73-I 1948). Two prominent shear zones: (a) North Purulia Shear Zone (NPSZ) and (b) South Purulia Shear Zone (SPSZ) (marked in figure 1) are known to occur in the Purulia district. The SPSZ trends almost EW and passes through the south of Balarampur. This shear zone shows phosphate and other mineralisation. Figure 2 demonstrates the field photograph of highly foliated gneissic rocks from CGGC indicating prominent weathering along foliations. Figure 3 exhibits the highly fractured phyllite.

\section{Methodology}

The following are the details of the methodology adopted in the present study.

\subsection{Laboratory studies}

Lithological (figure 1) and lineament (figure 4) thematic maps have been created from the Geocoded 73-I/4, 73-I/8 (1) and 73-I/8 (2) satellite imageries of IRS-P6 standard (band 23 ) false colour composite (FCC) on the base map, prepared using the Survey of India toposheets numbered 73-I/4 and $73-\mathrm{I} / 8$ at $1: 50,000$ scale. Lineament map has been prepared by detecting and tracing lineaments

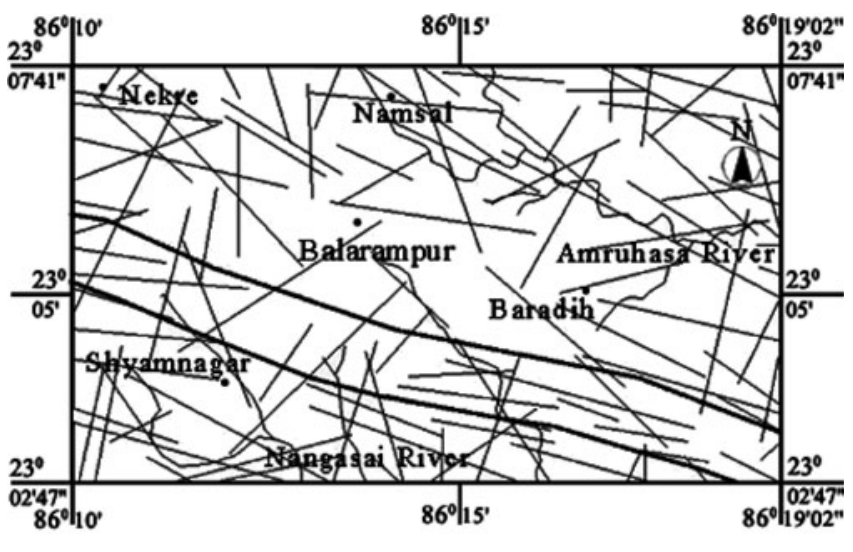

Index

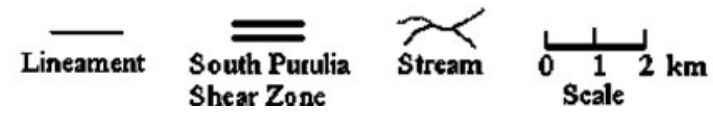

Figure 4. Map of the area showing the geologic lineaments. 
from satellite imageries on the basis of textural, soil tonal, vegetation, topographic and drainage linearities (Lillesand 1989; Drury 1990; Gupta 1991) by visual interpretation. The non-structural and 'false' lineaments have been eliminated after comparing lineament map with the corresponding toposheets $(73-\mathrm{I} / 4,73-\mathrm{I} / 8)$ and field verification leaving the 'geologic lineaments'. The lithological map (figure 1) has been prepared by visual interpretation of the satellite imageries and field investigation. The structural data featuring joints/fractures, foliations and lineament orientations have been analysed very critically. The lineaments for fracture-correlation have been categorized as in Moore et al (2002). These are:

- unfiltered lineament analysis technique which involves comparison of all lineament data with all fracture data of the entire area.

- filtered, domain-based fracture-correlated lineaments which has been determined by defining fracture families for each grid. The study area has been divided into 15 grid-cells, each cell with dimension of $3 \times 3 \mathrm{~km}$, containing three or more sample points.

- filtered, discrete-analysis-based fracturecorrelated lineaments that has been determined by defining structural data for each grid. Squarecell sampling grids have been developed similarly to that of the second technique. This technique examined lineaments by comparing their trends in a dataset with the strike of steeply dipping planar structural features within the same grid. Georient software has been used for quantitative and statistical analyses on lineaments, fractures and foliations. Since the measurements have been taken between $0^{\circ}$ and $180^{\circ}$ and the circular distributions have been plotted on unit circles with $10^{\circ}$ class intervals, the 18 classes before plotting have been duplicated.

\subsection{Field studies}

The field studies were made for ground-truth investigations of photo-lineament location, geometry, continuity and reasons for the abrupt termination, lithology and fracture and other structural features. The field study shows that fracture trends, anomalous topography, contact of lithounits, natural alignment of trees, rivers and streams are the representatives of lineaments on the ground. Some lineaments have, however, not been traceable on the real ground. Foliation is prominent in quartz-biotite granite gneiss, porphyroblastic granite gneiss, epidiorites, mica schist and phyllite. A shear zone underlain by mica schist has a width of about $1.5 \mathrm{~km}$ and passes through the south of
Balarampur along EW direction. Rock exposures displaying $3-\mathrm{D}$ visualisation of the fracture and other structural data has always been selected for data recording. Measurements have been made of:

- attitude (strike and dip) of joint/fracture sets,

- frequency of fracture planes (number of planes in a meter across a normal line),

- length of the fractures,

- attitude (strike and dip) of the foliation and the schistosity of the rocks, and

- aperture of the fractures.

Foliations dip steeply (ranging from $57^{\circ}$ to $90^{\circ}$ ) northward. For statistical significance, the attitude of a set of fractures has been taken as the average of three measurements from different points of an outcrop (Mallik et al 1983). In this study only the orientation and fracture frequency of the fractures have been taken for analysis.

\section{Data analysis}

The joint/fracture planes dipping $45^{\circ}$ or more measured in the field have only been considered for the analysis since straight line lineaments are formed by steeply dipping planes (De'gnan and Clark 2002). In our analysis initially the unfiltered lineament analysis (Moore et al 2002) was done for comparison of all the lineament and fracture data of the whole area. Table 1 shows the frequency percentage of all lineament and fracture trends in the

Table 1. Frequency percentage of lineament and fracture trends.

\begin{tabular}{lcc}
\hline $\begin{array}{l}\text { Trend } \\
\text { interval }\end{array}$ & $\begin{array}{c}\text { Percentage of } \\
\text { lineament } \\
\text { frequency }\end{array}$ & $\begin{array}{c}\text { Percentage of } \\
\text { fracture } \\
\text { frequency }\end{array}$ \\
\hline $0-10$ & 3 & 8 \\
$10.1-20$ & 8 & 11 \\
$20.1-30$ & 4 & 5 \\
$30.1-40$ & 3 & 5 \\
$40.1-50$ & 3 & 5 \\
$50.1-60$ & 5 & 5 \\
$60.1-70$ & 3 & 5 \\
$70.1-80$ & 4 & 3 \\
$80.1-90$ & 4 & 4 \\
$90.1-100$ & 17 & 6 \\
$100.1-110$ & 11 & 3 \\
$110.1-120$ & 10 & 6 \\
$120.1-130$ & 10 & 4 \\
$130.1-140$ & 4 & 5 \\
$140.1-150$ & 3 & 9 \\
$150.1-160$ & 4 & 2 \\
$160.1-170$ & 3 & 8 \\
$170.1-180$ & 3 & 5 \\
\hline
\end{tabular}




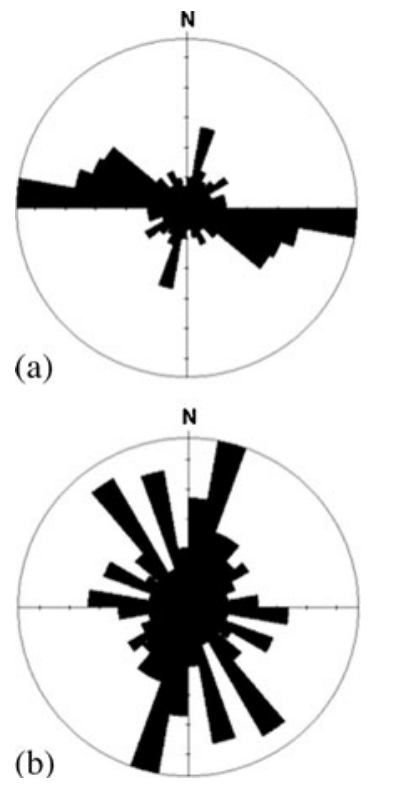

Figure 5. Azimuth-frequency (rose) diagrams of (a) lineament orientations and (b) fracture orientations in the study area.

study area. The unfiltered lineament analysis for all lineaments and fractures, as shown in rose diagrams (figure 5), clearly demonstrated dominant lineament geometry along EW (43\%) (figure 5a) while the fractures are distributed between $20^{\circ}$ and $40^{\circ}(32 \%)$ (figure $\left.5 \mathrm{~b}\right)$, revealing a significant discordance between lineament and fracture trend in the area. Broadly, these findings contradict the main idea inherent in performing any lineament analysis that lineament trends represent fracture zones (Mabee et al 1994).

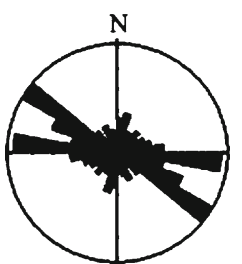

(a) Lineament

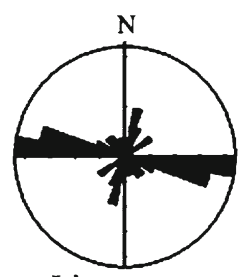

(b) Lineament

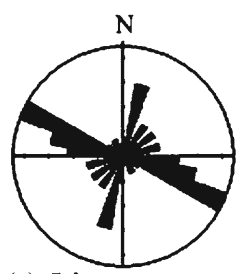

(c) Lineament
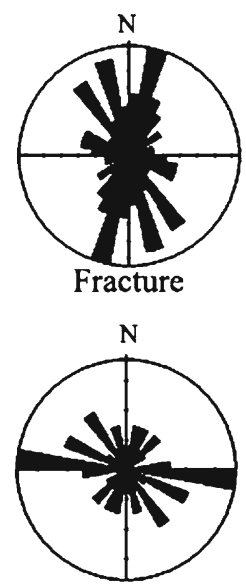

Fracture

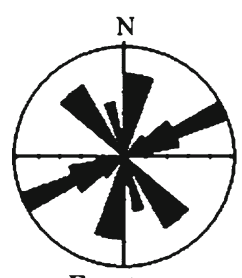

Fracture
Figure 7. Lineament rosettes and fracture rosettes in (a) the northern domain (D1), (b) the shear zone (D2), and (c) the southern domain (D3).

The total area under study has been classified into 15 square grid cells each having dimension $3 \times 3 \mathrm{~km}$ to perform the filtered, domain-based fracture-correlated lineament analysis (Moore et al 2002). Representative lineament and fracture families of each cell have been plotted as frequencyazimuth (rose) diagrams using the Georient Software (figure 6) showing clear discrepancy between

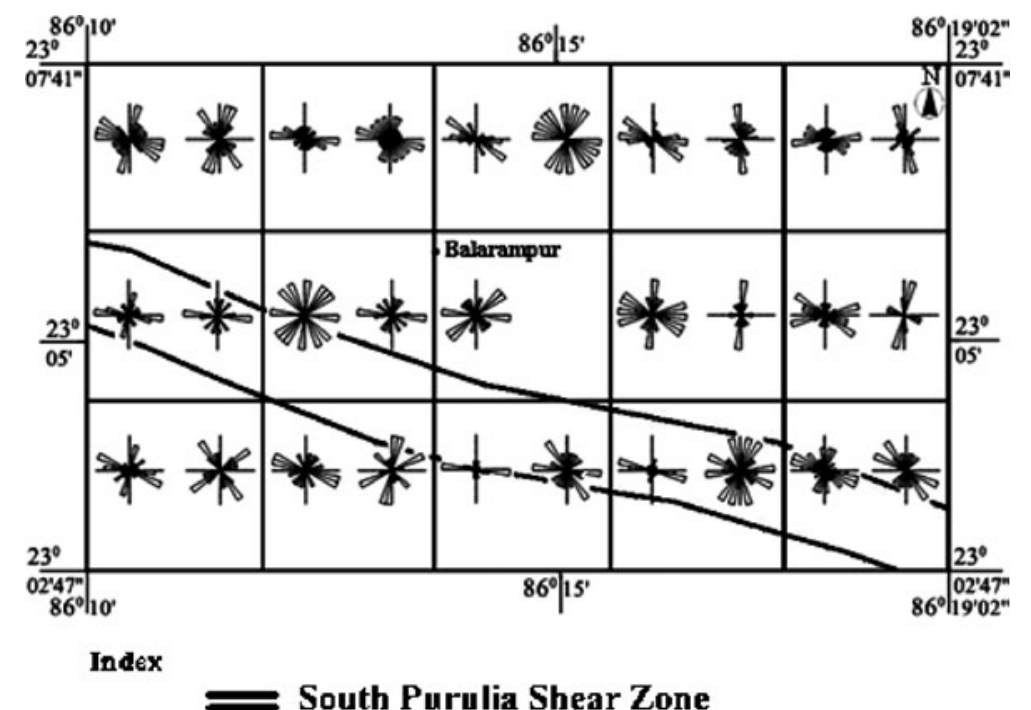

Figure 6. Map showing spatial distribution of lineament rosettes and fracture rosettes in grid cells $(3 \times 3 \mathrm{~km}$ in size). In each grid cell, lineament rosette is shown in left-hand side and fracture rosette in right-hand side. 
Table 2. Comparison of major lineament and fracture trends in the three domains.

\begin{tabular}{lccc}
\hline Major trends & $\begin{array}{c}\text { North of shear } \\
\text { zone (D1) }\end{array}$ & $\begin{array}{c}\text { Within shear } \\
\text { zone (D2) }\end{array}$ & $\begin{array}{c}\text { South of shear } \\
\text { zone (D3) }\end{array}$ \\
\hline $\begin{array}{l}\text { Lineament trends } \\
\text { Fracture trends }\end{array}$ & E-W, NW-SE & E-W & WNW-ESE \\
\hline
\end{tabular}

the prominent lineament direction(s) and prominent fracture direction(s) of each cell, except those within the SPSZ.

As the study area occurs at the junction of the Chhotanagpur and Singhbhum cratons comprising a shear zone in between, the grid cells in the northern part of the shear zone have been fused to form a single domain. Similarly the grid cells contained in the shear zone and those in the southern part of the shear zone have been clubbed into two separate domains. Thus the area has been divided into three domains:

- region occurring north of shear zone (D1),

- the region within the shear zone (D2), and

- the region south of the shear zone (D3).

The lineament and fracture trends of each domain have been presented separately (figure 7) and listed in table 2. In D1, the lineaments trend chiefly along EW and NW-SE directions and the dominant fractures $(37 \%)$ trend along NS direction, indicating fracture non-correlated lineaments (figure 7a). The domain, D2, shows both lineaments $(46 \%)$ and fractures $(37 \%)$ trending along the EW direction (figure $7 \mathrm{~b}$ ), indicating a strong agreement of the lineament and fracture trends and hence the lineaments can be designated as fracture-correlated. In D3, the dominant lineament and fracture trends are respectively along WNW$\mathrm{ESE} / \mathrm{N}-\mathrm{S}$, the former being more prominent, and NE-SW (38\%)/NS (30\%) directions (figure 7c), clearly indicating dominant lineaments to be fracture non-correlated and NS trending intermediate lineaments to be fracture-correlated. The analysis shows fracture non-correlated lineaments in D1 and D3. Comparison of figures 5 and 7 will immediately indicate the use of filtering technique for analysis of correlation between lineaments and fractures.

Mainly four lithology types are exposed in the area, i.e., granite gneiss, mica schist, phyllite and epidiorite. The lineament and fracture trend data as recorded from these lithologies have been classified in table 3 , and their rose diagrams in figure 8 indicate the effects of lithology on them. The granite gneiss, traversed by NW-SE trending lineaments, has developed fractures largely trending along NNE-SSW directions (figure 8a). The mica schist has EW trending lineament with fractures orienting along EW and NW-SE directions (figure 8b). In phyllite, the dominant lineament trends is EW, while the fracture trends are given by NNE-SSW and NW-SE directions (figure 8c). The epidiorites have the lineaments along NNESSW and ESE-WNW directions and the fractures along EW and NS directions (figure 8d). Comparison of lineament with lithology shows different lineament and fracture trends except between mica schists and phyllites. Similar trends in lineaments and fractures in mica schists and phyllites may be due to ductile nature of rocks.

Further, in order to study the effect of rock type on the fracture and lineament correlation, the lineaments and fractures of mica schist have sorted out which occur within and outside the shear zone. The mica schist has EW directions for both the fracture and lineament in the shear zone, as shown in figure 9(a) and has NW-SE and WNW-ESE directions for the lineament and NS directions for the fractures outside shear zone, as represented in

Table 3. Comparison of major lineament and fracture trends in the lithology types.

\begin{tabular}{llc}
\hline Lithology & $\begin{array}{c}\text { Major lineament } \\
\text { trends }\end{array}$ & $\begin{array}{c}\text { Major fracture } \\
\text { trends }\end{array}$ \\
\hline Granite gneiss & NW-SE & NNE-SSW \\
Mica schist & E-W & E-W, NW-SE \\
Phyllite & E-W & NNE-SSW, \\
& & NW-SE \\
Epidiorite & NNE-SSW, & E-W, N-S \\
& ESE-WNW & \\
\hline
\end{tabular}




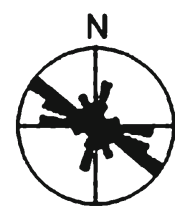

Lineament

(a)

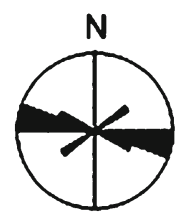

Lineament

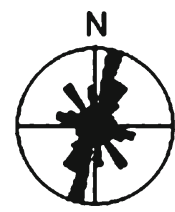

Fracture

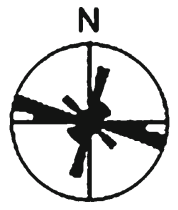

Lineament

(b)

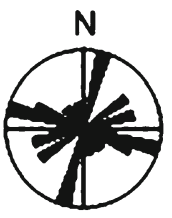

Lineament

(d)

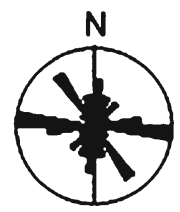

Fracture

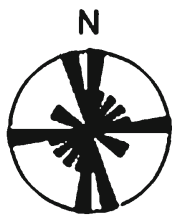

Fracture (c)

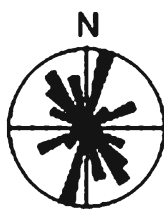

Fracture

Figure 8. Azimuth-frequency (rose) diagrams showing lineament orientation and fracture orientation in the lithology types. (a) Granite gneiss, (b) mica schist, (c) phyllite, and (d) epidiorite.

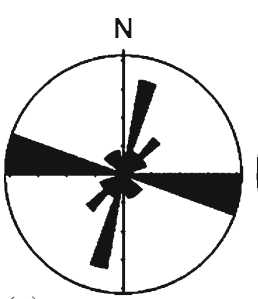

(a) Lineament
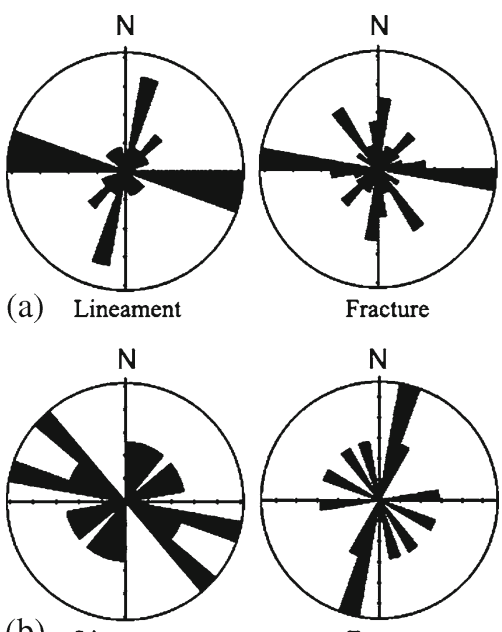

(b)

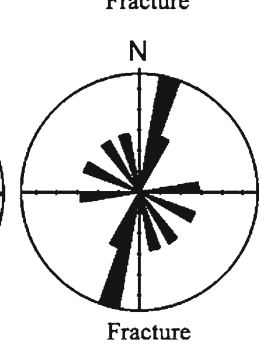

Figure 9. Azimuth-frequency rosettes showing lineament orientation and fracture orientation in mica schist: (a) within the shear zone and (b) outside the shear zone.

figure 9(b). This shows that mica schist produces fracture-correlated lineaments in the shear zone but outside the shear zone their correlation is not significant indicating that the correlation of lineament is also dependent on other structures than fractures.

Foliation plane, which is commonly developed as a result of tectonic strain is one of the important structural features of metamorphic rocks, perhaps need consideration in the analysis of lineaments for fracture correlations. Azimuth-frequency (rose) diagrams of representative foliation families of each domain (i.e., D1, D2 and D3) have been constructed (figure 10) and compared with trends of
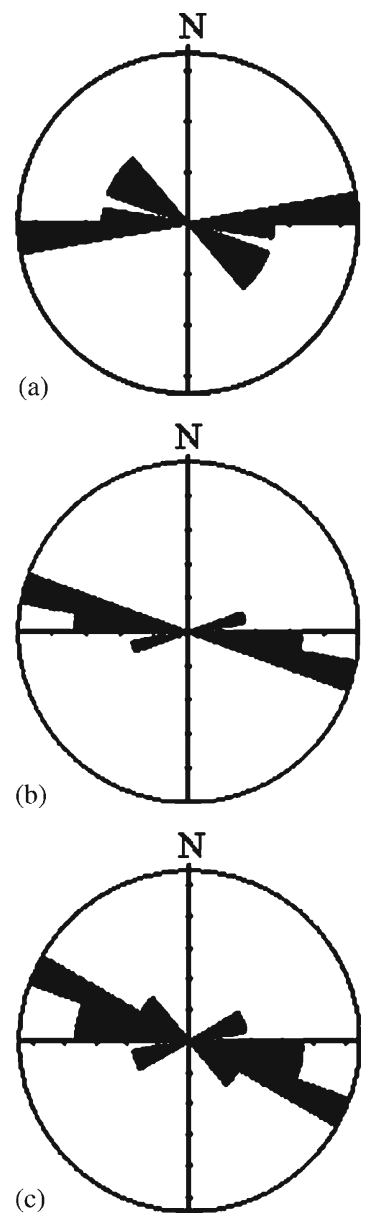

Figure 10. Azimuth-frequency (rose) diagrams of foliation orientation in (a) the northern domain (D1), (b) the shear zone domain (D2), and (c) the southern domain (D3).

lineaments of the corresponding domain to perform the filtered, discrete-analysis-based technique, indicating foliation-parallel lineaments trending along $\mathrm{EW} / \mathrm{NW}-\mathrm{SE}$ directions in D1 (figure 10a) and WNW-ESE in D3 (figure 10c). In D1, granite gneiss displays prominent alteration zones along the foliation planes (figure 2), developing lineaments paralleling foliations. The mica schist, phyllite and epidiorite in D3 show prominent structural discontinuities like schistosity and foliation, developing lineaments along foliations. Thus, metamorphic rocks outside the shear zone reveal a significant effect of foliations on the lineament orientations. As there has been no evidence of fault zones/fractures parallel to these directions, the lineaments may be designated as 'foliationcorrelated' which is strongly controlled by the tectonic strain history of the region. In D2, EW trending foliations (figure 10b) perhaps combine with dominant fractures to produce lineaments with high fracture correlation.

Frequency of joints/fractures, measured as number of joint planes of a particular set crossed 
in a perpendicular traverse of $1 \mathrm{~m}$, ranges from 1 to 34 per meter in the study area. More closely spaced fractures with higher frequency may represent more potentially transmissive bedrocks (Mabee and Hardcastle 1997). Though fracture frequency database is not very large, the scatter-plots between fracture strike and fracture frequency, constructed for the each domain, D1, D2 and D3, using Statistica software (figure 11) show a very interesting feature. The fracture set, striking EW, exhibits higher frequency $(>15 / \mathrm{m})$ in the domain of shear zone (D2) (figure 11b), paralleling the trend of fracture-correlated lineaments. In the domains D1 and D3, fractures show lower frequencies $(<15 / \mathrm{m})$ (figure 11a and c), except the NS trending fractures in D3 which is typified by higher fracture-frequency $(>15 / \mathrm{m})$, perhaps corresponding the NS trending intermediate fracture-correlated lineaments in D3.
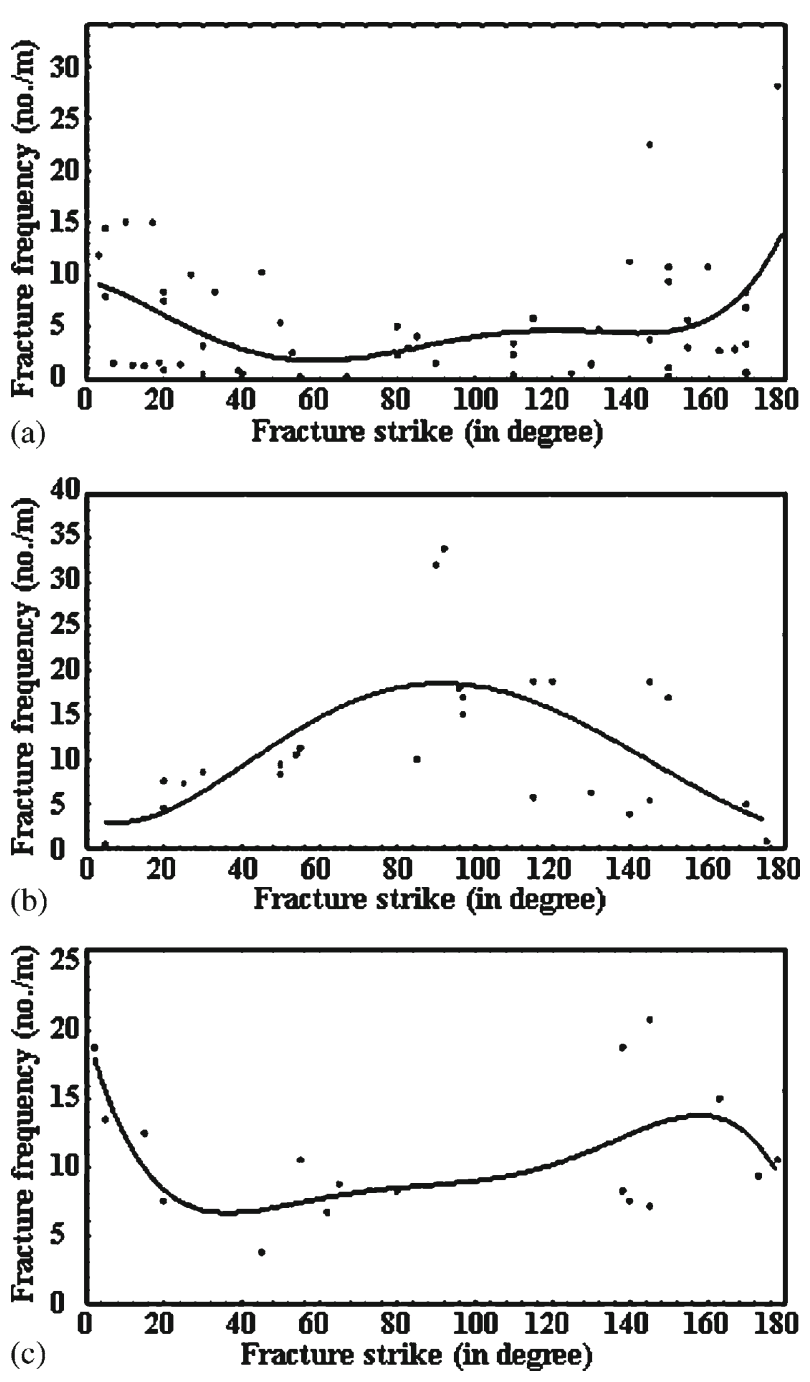

Figure 11. Graphs illustrating the relationship between fracture frequency and fracture strike. (a) Northern domain (D1), (b) shear zone domain (D2), and (c) southern domain (D3).

\section{Discussion and conclusions}

The lineament swarms derived from remotely sensed imageries over a Precambrian metamorphic terrain at the CGGC-SG region have been checked for ground truth verification followed by recording of outcrop-scale fracture and other data. Unfiltered lineament analysis technique fails to identify overall correlation between lineaments and fractures in the study area. Using filtered techniques of analysis, it is possible to locate the areas where lineament and fracture domains of similar trend overlap. The filtered, domain-based fracture analysis reveals the occurrence of fracture-correlated lineaments in the shear zone (D2). The shear zone comprising chiefly mica schist has EW trending fracture and lineament constituting respectively $37 \%$ and $46 \%$. The mica schist has also steeply dipping schistosity planes striking along EW directions, like that of fracture planes. The lineaments are characteristically longer in the shear zone than in the other areas.

In northern domain (D1), granite gneiss clearly exhibits majority of the lineaments oriented along foliations rather than along the fractures with low fracture-frequency $(<15 / \mathrm{m})$. This may be attributed to the enhanced weathering of the rocks along the foliation planes. Therefore, the more intense and pervasive foliation planes are perhaps favoured to produce lineaments in metamorphic rocks and may be designated as 'foliationcorrelated' lineaments. The shear zone (D2), comprising chiefly mica schist, shows strong concordance between trends of lineaments and fractures, with high fracture-frequencies $(>15 / \mathrm{m})$ and the lineaments are assigned to be 'fracturecorrelated'. The mica schist has steeply dipping schistosity planes striking along EW directions, paralleling the shear zone trend. The transport and distribution of fluids, strongly controlled by the shear zone, may facilitate to develop 'fracturecorrelated' lineaments. In southern domain (D3), majority of the lineaments are fracture noncorrelated, oriented along foliations and, therefore, assigned as foliation-correlated. Intermediate fracture-correlated lineaments are concordant to the fractures characterized by high $(>15 / \mathrm{m})$ fracture-frequencies.

Weathering and kaolinization as a result of limited movement of groundwater along foliations, common in gneisses, may raise preferential moisture content along foliations (Ross and Frohlich 1993), forming foliation-correlated lineaments. Brecciated rocks adjacent to the shear zones, as well as the shear zones themselves, can be hydraulically conductive inducing preferential groundwater movement as supported by several researchers (Beamish 1995; Seaton and Burbey 
2000, 2005; Harinarayana et al 2006; Choudhary and Kunar 2007; Rugh and Burbey 2008;) and form lineaments along fractures. High fracturefrequency means closely spaced fractures. Enhanced permeability associated with the fracture set, showing high fracture-frequency, characterizes differential moisture content along the fractures favouring development of fracture-correlated lineaments. This is rightly pointed out by several researchers (Braathen 1999; Henriksen and Braathen 2006). More closely the fractures are placed, the more is the tendency of groundwater to flow along those closely spaced fractures, causing potential weathering along the flow path, facilitating to produce fracture-correlated lineaments.

Fracture non-correlated lineaments may limit its use in groundwater supply and other applications. Results show that the fracture-correlated lineaments traversing the shear zone may perhaps be further enhanced by foliation and high fracture frequency of the rocks. The lineaments exhibited in the areas off the shear zone geographically correlate with foliation planes developed by the regional stress field of the rocks, thus qualifying the lineaments as 'foliation-correlated'. The present analysis indicates that the fracture frequency and tectonic strain history of the region may have played significant roles in the formation of lineaments in the older metamorphic rocks.

\section{Acknowledgements}

The authors are thankful to the University Grants Commission (UGC), India and Department of Science and Technology (DST)-FIST, Government of India for infrastructural and financial support. They are also grateful to Dr P S Chakraborty, Principal Scientist, DST, Government of West Bengal, India for the valuable advice in lineament map preparation.

\section{References}

Acharya T and Chatterjee A 2010 Fracture-correlated lineaments and groundwater prospect; Abstract, Proc. National Seminar on Sedimentation, Tectonics and Hydrocarbon Potential in Himalayan Foreland Basin, University of Jammu, Jammu, pp. 44-45.

Acharya T, Basumallik S and Paul S K 2007 Comparative analysis of lineaments and fractures in Precambrian crystalline rocks using remote sensing and field technique: A case study in and around Balarampur, Purulia District, West Bengal, India; Abstract, Proc. International Conference on Precambrian Sedimentation and Tectonics and Second GPSS Meeting, 10-12 December 2007, IIT Bombay, Mumbai, pp. 68-69.

Baidya T K 1992 Apatite-magnetite deposit in the Chhotanagpur Gneissic Complex, Panrkidih area, Purulia District, West Bengal; Indian J. Geol. 64(1) 88-95.
Beamish D 1995 Deep resistivity imaging across the northern and central belts of the Southern Uplands; Geol. Mag. 132 531-538.

Blanchet P H 1957 Development of fracture analysis as an exploration method; Am. Assoc. Pet. Geol. Bull. 40 1748-1759.

Boyer R and Mcqueen J 1964 Comparison of mapped rock fractures and airphoto linear features; Photogram. Eng. Remote Sens. 30 630-635.

Braathen A 1999 Kinematics of post-Caledonian polyphase brittle faulting in the Sunnfjord region, western Norway; Tectonophys. 302 99-121.

Brown N 1994 Integrating structural geology with remote sensing in hydrogeological resource evaluation and exploration; Proc. Tenth Thematic Conference in Geologic Remote Sensing, San Antonio, TX 1 144-154.

Caran C S, Woodruff C M Jr and Thompson E J 1982 Lineament analysis and inference of geologic structures examples from the Balcones/Ouachita trend of Texas; University of Texas at Austin, Bureau of Economic Geology, Geological Circular 82(1) 59-69.

Choudhary P K and Kunar S 2007 A case study for geotechnical investigation for assessment of subsurface conditions for tunnel no. 2 of katra quazigund rail link project; Abstract, Proc. Workshop on Tunnelling in Himalayan Geology, Katra, J\&K, Water and Energy 16(3) $218-230$.

De'gnan J R and Clark S F Jr 2002 Fracture-correlated lineaments at Great Bay, Southeastern New Hampshire; U.S. Geological Survey Open-File Report 02-13.

Dhakate R, Singh V S, Negi B C, Chandra S and Rao V A 2007 Geomorphological and geophysical approach for locating favorable groundwater zones in granitic terrain, Andhra Pradesh, India; J. Environ. Manag., doi: 10.1016/j.jenvman.2007.07.014.

Drury S A 1990 Image Interpretation; In: Geology, 2nd edn., Chapman \& Hall, London.

Garza L D L and Slade R M 1986 Relations between areas of high transmissivity and lineaments - the Edwards aquifer, Barton springs segment, Travis and Hays counties; In: The Balcones Escarpment, Geology, Hydrology, Ecology and Social Development in Central Texas (eds.) Abbott P L, Woodruff CM Jr, The University of Texas Libraries, The University of Texas at Austin, pp. 131-144.

Geological Quadrangle Map 73-I 1948 Geological Survey of India, Calcutta.

Gupta R P 1991 Remote Sensing Geology; Springer-Verlag, Germany.

Gupta A and Basu A 2000 North Singhbhum Proterozoic mobile belt Eastern India - A review; Geol. Surv. India Spec. Publ. 55 195-226.

Harinarayana T, Naganjaneyulu K and Patro B P K 2006 Detection of a collision zone in south Indian shield region from magnetotelluric studies; Gondwana Res. 10 48-56.

Henderson G 1960 Airphoto lineaments in Mpanda area, Western Province, Tanganyika, Africa; Am. Assoc. Pet. Geol. Bull. 44 53-71.

Henriksen $\mathrm{H}$ and Braathen A 2006 Effects of fracturelineaments and in situ rock stresses on groundwater flow in hard rocks: A case study from Sunnfjord, Western Norway; Hydrol. J. 14 444-461.

Hodgson R A 1961 Regional study of jointing in Comb Ridge-Navajo Mountain area, Arizona and Utah; Am. Assoc. Pet. Geol. Bull. 45 1-38.

Katti V J, Sen J and Bhatt A K 2010 Uranium potentiality of South Purulia Shear Zone in Eastern Indian Shield; Technical Meeting on Low Grade Uranium Ore, 29-31 March 2010, International Atomic Energy Agency (IAEA), Vienna, Austria. 
Kazemi R, Porhemmat J and Kheirkhah M 2009 Investigation of lineaments related to groundwater occurrence in a karstic area: A case study in Lar catchment, Iran; Res. J. Environ. Sci. 3(3) 367-375.

Lattman L H and Matzke R H 1961 Geological significance of fracture traces; Photogram. Eng. 27 435-438.

Lattman L H and Segovia A V 1961 Analysis of fracture trace pattern of Adak and Kagalaska Islands, Alaska; $\mathrm{Am}$. Assoc. Pet. Geol. Bull. 45 249-251.

Lattman L H and Parizek R R 1964 Relationship between fracture traces and the occurrence of groundwater in carbonate rocks; J. Hydrol. 2 73-91.

Lillesand T M 1989 Remote Sensing and Image interpretation; Wiley, USA.

Lipfert G, Tolman A and Loiselle M 2001 Modeling recharge zones in fractured bedrock for Maine's Source Water Assessment Program; Fractured Rock, Toronto, Ontario, Canada.

Mabee S B and Hardcastle K C 1997 Analyzing outcropscale fracture features to supplement investigations of bedrock aquifers; Hydrol. J. 5 21-36.

Mabee S B, Hardcastle K C and Wise D U 1994 A method of collecting and analyzing lineaments for regionalscale fractured bedrock aquifer studies; Groundwater $\mathbf{3 2}$ 884-894.

Mah A, Taylor G R, Lennox P and Balia L 1995 Lineament analysis of Landsat Thematic Mapper Images, Northern Territory, Australia; Photogram. Eng. Remote Sens. 61 761-773.

Mallik S B, Bhattacharya D C and Nag S K 1983 Behaviour of fractures in hard rocks - a study by surface geology and radial VES method; Geoexploration 21 181-189.

Matzke R H 1961 Fracture trace and joint patterns of Western Centre County, Pennsylvania; MS thesis, The Pennsylvania State University.
Moore R B, Schwarz G E, Clark S F Jr, Walsh G J and Degnan J R 2002 Factors related to well yield in the fractured-bedrock aquifer of New Hampshire; US Geol. Surv. Prof. Paper 1660.

Nag S K 1999 Hydrogeomorphic and fracture studies for groundwater investigation in and around Balarampur, Purulia District, West Bengal; ERIM Int. Conf., Vancouver, Canada VI 507-514.

O'leary D W, Freidman J D and Pohn H A 1976 Lineament, linear, lineation: Some proposed new definitions for old terms; Geol. Soc. Am. Bull. 87 1463-1469.

Parizek R R 1976 On the nature and significance of fracture traces and lineaments in carbonates and other terrains; Karst Hydrology and Water Resources, Proceedings of the US-Yugoslavian Symposium, Dubrovnik, Yugoslavia, pp. 47-100.

Peterson R 1980 Lineament analysis for oil and gas exploration and production in Wyoming; Abstr. Am. Assoc. Pet. Geol. Bull. 64764.

Rahiman T I H and Pettinga J R 2008 Analysis of lineaments and their relationship to Neogene fracturing, SE Viti Levu, Fiji; Geol. Soc. Am. Bull. 120(11-12) 1544-1555.

Ross A L and Frohlich R K 1993 Fracture trace analysis with a geographic information system 'GIS'; Bull. Assoc. Eng. Geol. 30 87-98.

Rugh D F and Burbey T J 2008 Using saline tracers to evaluate preferential recharge in fractured rocks, Floyd County, Virginia, USA; Hydrol. J. 16(2) 251-262.

Seaton W J and Burbey T J 2000 Aquifer characterization in the Blue Ridge Physiographic Province using resistivity profiling and borehole geophysics: Geologic analysis; J. Environ. Eng. Geophys., doi: 10.4133/JEEG5.3.45.

Seaton W J and Burbey T J 2005 Influence of ancient thrust faults on the hydrogeology of the Blue Ridge Province; Ground Water 43(3) 301-313. 